\title{
Part I: Characterization of Flammability Behavior of Polyester Fabric Modified with Sol-Gel
}

\author{
A. A. Younis ${ }^{1}$, Kh. El-Nagar ${ }^{2} \&$ M. A. Nour ${ }^{1}$ \\ ${ }^{1}$ Fire and Explosion Protection (FEP), National Institute for Standards (NIS), Egypt \\ ${ }^{2}$ Textile Metrology Lab (TML), National Institute for Standards (NIS), Egypt \\ Correspondence: A. A. Younis, Fire and Explosion Protection (FEP), National Institute for Standards (NIS), Giza, \\ Egypt. Tel: 2-11-5252-6422. E-mail: dr_ahmedabdee@yahoo.com
}

Received: January 22, 2013 Accepted: March 19, 2013 Online Published: April 22, 2013

doi:10.5539/ijc.v5n2p38

URL: http://dx.doi.org/10.5539/ijc.v5n2p38

\begin{abstract}
Polyester (PET) fabric is insecure to use since it melts at $249-290{ }^{\circ} \mathrm{C}$, such molten PET could drip on underlying surfaces or human skin and hence becomes harmful. The rapidly ignited and flammable materials found in nearby areas might lead to damage life and property of consumers. In this research, the fabric was modified to avoid these disadvantages. Thus we investigate the effect of phosphorylated sol-gel coating material on UV/Ozone pre-modified polyester sample for different periods. The thermogravimetric analysis (TGA) and ignition properties (UL/94) were studied for all samples under test. The samples with phosphorylated sol-gel material improved the flammability behavior. Also, the use of UV/Ozone prior this modification activate the surface of polyester, thus improved the stability of the flame retardant.
\end{abstract}

Keywords: PET, sol-gel, flammability, flame chamber

\section{Introduction}

PET is a synthetic polymer namely polyethylene terephthalate. It has many advantages so it is widely used in many fields as: automotive industries, textiles and garments. It can be used in two ways: as a raw material by itself or as a blend, because of its wrinkle-resistant property and its ability to retain its shape (Boekhoff, accessed on 2012, September 16). However, its flammability is so danger due to the dripping, smoking and shrinking effects. For these reasons, it is necessary to improve the anti-dripping and fire retardant properties of PET. The most important ways to protect polyester fiber from burning are: the first way is copolymerization of PET with a reactive flame-retardant monomer. The second way is the addition of flame retardants into PET during processing; and the third way is flame-retardant treatment of PET fabrics. In fact, the flame-retardant treatment has been widely used due to its relative convenience and inexpensiveness in comparison with the other two ways (Lerdkajornsuk \& Charuchinda, 2010).

Recently, several papers have reported the improvement of flame retardancy and anti-dripping of polymer using montmorillonite (Kuenpong \& Charuchinda, 2009; Song et al., 2005). The presence of montmorillonite or nanoclays in polypropylene (PP) or other polymers was improved the rate of burning (Nour et al., 2010). Flame-retardant materials are used in a wide range of applications e.g. textile, aerospace and automotive application (Erdem et al., 2009; Mostashari, 2008). Nowadays, many studies on the fire retardancy of PET have been done, in particular, different additives such as: phosphorus species (Chapple \& Ferg, 2006; Zhu et al., 2004; Rohringer et al., 1975; Goodman \& Sheanan, 1990; Ge, 2008; Asrar, 1999), silica particles (Sequeira et al., 2007) and halogen compounds (Wilson et al., 1969) have been investigated to reach this goal.

The sol-gel process involves the growth of inorganic networks through the formation of a colloidal suspension (sol) and gelation of the sol to form a network in a continuous liquid phase (gel) (Hribernik et al., 2007; Younis et al., 2012; Uddin et al., 2007; Daoud \& Xin, 2004; Meilert et al., 2005; Bozzi et al., 2005; Abidi et al., 2007; Wang et al., 2004). The precursors for synthesizing these colloids consist of a metal or a metalloid element surrounded by various reactive legends. Metal alkoxides are the most popular because they react readily with water. Sol-gel derived products have numerous applications such as: synthesis of the lightest materials and some of the toughest ceramics, optics, and electronics (Klein, 1994; Wright \& Sommerdijk, 2001; Aegerter et al., 2004; Philippou, 2000; Brinker \& Scherer, 1990; Geffcken et al., 1943). The technique of sol-gel process depends on 
two steps: hydrolysis and condensation reactions. The mechanisms of hydrolysis and condensation, and the factors (organic radical of the OR-group, solvent, catalyst, concentration and temperature) that have a bias toward linear or branched structures are the most critical issues of sol-gel science and technology (Dislich, 1971; Matijevic, 1986; Brinker \& Mukherjee, 1981; Sakka \& Kamiya, 1980; Yoldas, 1979; Prochazka \& Klug, 1983; Ikesue et al., 1995; Ikesue, 2002).

$$
\mathrm{M}(\mathrm{OR})_{4}+\mathrm{xH}_{2} \mathrm{O} \rightarrow \mathrm{M}(\mathrm{OH})_{\mathrm{x}}(\mathrm{OR})_{4-\mathrm{x}}+\mathrm{xROH}
$$

Condensation reaction is a chemical reaction in which two molecules combine to form a siloxane [ $\mathrm{Si}-\mathrm{O}-\mathrm{Si}$ ] bond with loss of water or alcohol (Müller, 1994). In a condensation reaction two partially hydrolyzed molecules can link to form:

$$
(\mathrm{RO})_{3}-\mathrm{Si}-\mathrm{OH}+\mathrm{HO}-\mathrm{Si}-(\mathrm{OR})_{3} \rightarrow(\mathrm{RO})_{3} \mathrm{Si}-\mathrm{O}-\mathrm{Si}(\mathrm{OR})_{3}+\mathrm{H}-\mathrm{O}-\mathrm{H}
$$

or

$$
(\mathrm{RO})_{3}-\mathrm{Si}-\mathrm{OR}+\mathrm{HO}-\mathrm{Si}-(\mathrm{OR})_{3} \rightarrow(\mathrm{RO})_{3} \mathrm{Si}-\mathrm{O}-\mathrm{Si}(\mathrm{OR})_{3}+\mathrm{R}-\mathrm{OH}
$$

These types of condensation reactions continue to build larger and larger silicon-containing molecules by the process of polymerization. Figure (1) illustrates the molecular structure, which produced as a result of the reaction between silica gel and phosphoric acid in the last stage of sol-gel coating preparation (Bamoniri et al., 2012).

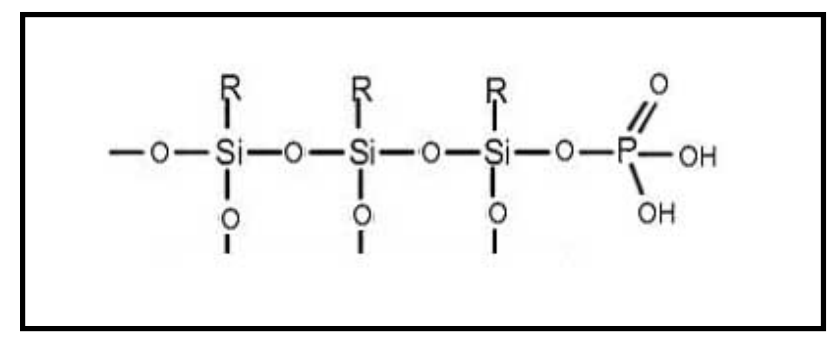

Figure 1. Scheme for the molecular structure which produced as a result of the reaction between silica gel and phosphoric acid

This research work aims to improve the thermal and ignition properties of polyester samples. PET was activated by UV/Ozone for different periods then coated with phosphorylated sol-gel. All the samples were tested for TGA and flammability properties.

\section{Experimental Work}

\subsection{Polyester Fabric}

Mill-scoured raw polyester fabric of weight $140 \mathrm{~g} / \mathrm{m}^{2}$, plain 1/1 weave. It was provided by Misr Company for Spinning and Weaving, El-Mahala El-Kobra, Egypt. The fabric was washed with distilled water at $90{ }^{\circ} \mathrm{C}$ for 30 min and dried horizontally at ambient condition.

\subsection{Sol-Gel Treatment}

The coating solutions were prepared by mixing $5 \mathrm{ml}$ methyltrimethoxysilane (95\%, Alfa Aesor) and $2.5 \mathrm{ml}$ acetic acid (99\%, Tedia) as a catalyst under constant stirring for $10 \mathrm{~min}$ at ambient temperature. A mixture of ethanol and distilled water was added (the silane film was dissolved in ethanol as soon as it is formed so that no layer or a mono layer is left on the surface, by this way, samples can be subjected to various surface sensitive techniques) (Younis, 2011). The solution was stirred at ambient temperature for $60 \mathrm{~min}$ to complete hydrolysis and condensation reactions (Younis, 2012). Finally, a limited amount of phosphoric acid (85\%, Aldrich) was added to the final polymer with continuous stirring for $15 \mathrm{~min}$. The studied PET fabric sample was first exposed to UV/Ozone for different irradiation periods ranging from 30 to 125 minutes then immersed in the freshly prepared sol-gel solution for 2 min and finally padded under constant pressure for $\sim 100 \%$ uptake. The treated samples were dried at ambient condition.

\subsection{Testing and Analysis}

\subsubsection{Mechanical Behavior}

The tensile strength and percentage elongation at break of the samples were carried out according to the standard 
method (ASTM, 2009) using Shimadzu Universal Tester of (C.R.T)- type S-500 Japan.

\subsubsection{Flammability Test}

The burning behavior and molten drip of treated and untreated polyester were investigated under standard test method of ISO-1210 using flame chamber (UL/94) (ISO-1992). In this study, the samples were pinned tightly to the frame and held horizontal in a holder with the lower edge $0.5 \mathrm{~cm}$ on top of a $2 \mathrm{~cm}$ blue flame of burner. It is worthy to mention that, in this experiment the flame application time was set at 15 second. After the ignition, the time of ignition was subtracted from the total combustion's duration. The remaining time was then reported as the burning time and the distance was calculated after the fire passed the first line (after $2.5 \mathrm{~cm}$ ). Finally, the burning rate $(\mathrm{BR})$ was calculated using this law:

$$
\text { Burning Rate }(\mathrm{BR})=\text { Burning Distance }(\mathrm{mm}) / \text { Time }(\text { seconds }) \times 60
$$

Experiments were conducted under the condition of ambient temperature of $25 \pm 2{ }^{\circ} \mathrm{C}$ and relative humidity (RH \%) ranged between $45-50 \%$.

\subsubsection{Thermogravimetric Analysis (TGA)}

It is a technique used to determine the mass changes of a sample during thermal decomposion (Marazzato et al., 2007; Wu, 2008). Thermogravimetric analysis was done by Thermal Analyzer (TGA-50 Shimadzu Instrument) at heating rate of $10{ }^{\circ} \mathrm{C} / \mathrm{min}$ from $10{ }^{\circ} \mathrm{C}$ to $750{ }^{\circ} \mathrm{C}$ under $\mathrm{N}_{2}$ gas (flow rate: $30 \%$ ). The weight of tested sample was $6.2 \mathrm{mg}$. The lasted sample was placed in open platinum pans in the instrument.

\section{Results and Discussions}

\subsection{Effect of UV/Ozone Exposuring Time on Mechanical Behavior of PET}

The changes in the mechanical properties (tensile strength and percentage elongation at break) of blank unexposed PET fabric samples and those exposed to UV/Ozone treatments for different periods ranging from (0 min to $125 \mathrm{~min}$ ) are evaluated and the obtained results are represented in Table 1 . Table 1 shows that the breaking strength decreased with increasing the exposure to UV/Ozone due to the oxidation of polyester linkages in the polyester fabric structure (Ibrahim et al., 2012). The changes in the mechanical properties of the examined fabric during exposure reflect not only to the changes in the chemical structure of the polymer system but also to the sub-molecular organization, i.e., its morphology (Shao et al., 1999).

Table 1. Effect of UV/Ozone on mechanical properties of PET fibers

\begin{tabular}{ccccc}
\hline $\begin{array}{c}\text { Exposed time } \\
(\mathrm{min})\end{array}$ & $\begin{array}{c}\text { Braking strength } \\
(\mathrm{Kgf})\end{array}$ & $\begin{array}{c}\text { Std. Dev. } \\
( \pm)\end{array}$ & $\begin{array}{c}\text { Extension } \\
(\%)\end{array}$ & $\begin{array}{c}\text { Std. Dev. } \\
( \pm)\end{array}$ \\
\hline 0 & 55.60 & 0.4261 & 38.27 & 0.5220 \\
30 & 53.80 & 2.8120 & 38.52 & 1.1880 \\
90 & 49.60 & 5.2500 & 31.42 & 0.3677 \\
125 & 48.31 & 2.1990 & 27.32 & 3.1110 \\
\hline
\end{tabular}

Table 1 shows the results of elongation of the samples exposed to UV/Ozone for different periods up to 125 minutes. Exposuring to time up to 30 minutes shows no significant change in the elongation characteristic but exposuring to longer time from 90 minutes and above shows significant decrement. This can be attributed to the oxidation and slight melt of PET fibers. Decrement of breaking strength was not drastic decrement because the $\mathrm{UV} /$ Ozone act predominantly on the fabric surface exposed.

\section{$3.2 U L / 94$}

Figure 2 illustrates the ignited treated and untreated samples. Untreated sample (a) was molten and many ignited droplets were dropped during flaming. Sample treated with sol-gel coating without exposuring to UV/Ozone (b) was burned completely during a wider period without melting resulting in char (by the time it was totally ignited). 


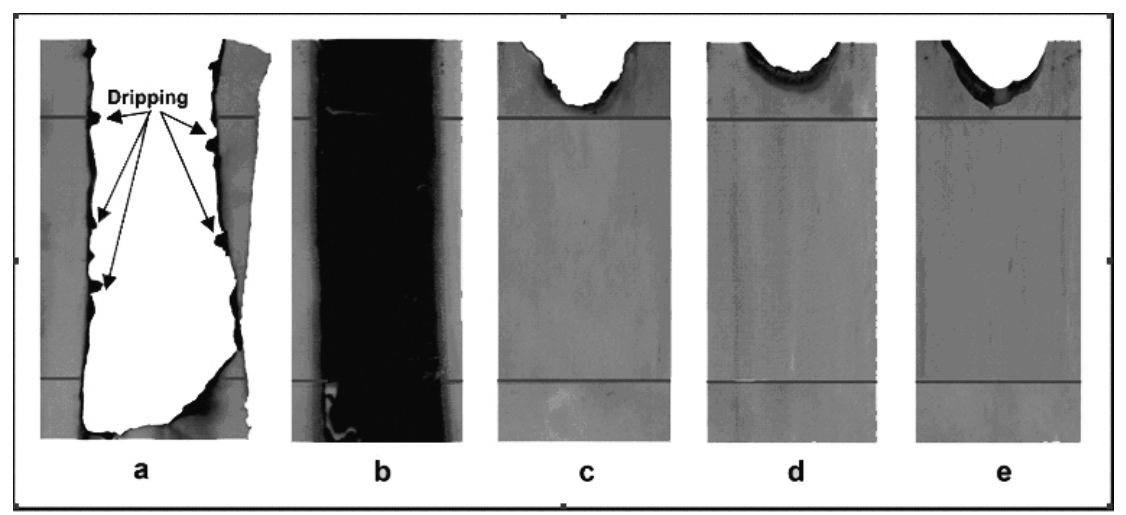

Figure 2. Flammability behavior of different polyester samples namely (a) blank polyester, (b) coated without exposed to UV/Ozone, (c) coated with sol-gel containing $\mathrm{H}_{3} \mathrm{PO}_{4}$ after exposed to UV/Ozone for $30 \mathrm{~min}$, (d) coated with sol-gel containing $\mathrm{H}_{3} \mathrm{PO}_{4}$ after exposed to UV/Ozone for 90 min and (e) coated with sol-gel containing $\mathrm{H}_{3} \mathrm{PO}_{4}$ after exposed to UV/Ozone for $125 \mathrm{~min}$

Samples (c-e) were treated with the sol-gel coating after irradiated to UV/Ozone for different periods ranged from $30 \mathrm{~min}$ to $125 \mathrm{~min}$. Sample (d) was considered as the most fire retardant sample. Samples (c) and (e) showed lower fire retardancy than sample (d) because sample (c) had in sufficient exposure time to produce enough free radicals which are able to combine with the coating sol-gel material. Mean while, sample (e) was exposed to UV/Ozone for longer time that caused excessive oxidation extent on polyester surface. Regardless the ordering of the flammability of the three samples (c-e), all samples showed good flame retardant behavior.

The experimental results included in Table 2 indicated that the untreated blank sample was classified into class-3 (ISO-1992) due to fast burning with dripping of ignited PET droplets and fabric shrinkage. This class is unsafe class because it has strong adhesive with the human skin during PET burning. The coated sample without exposuring to UV/Ozone was classified into class-3 due to its complete burning without shrink even with longer periods. This gives a chance to people in the venue of ignition to escape with enough safety extent. On the other hand, the exposured samples followed by treatment with sol-gel coating were classified into class-1(ISO-1992). Sol-gel treated coating materials with $\mathrm{H}_{3} \mathrm{PO}_{4}$ showed improvement in flammability behavior for all UV/Ozone exposured samples (30 min-125 min). Figure 2 illustrates that sample (d) has lower burning than samples (c and e). 
Table 2. The effect of UV/Ozone on the flame retardancy imparted to polyester fabric (plain $140 \mathrm{~g} \mathrm{~m}^{-2}$ )

\begin{tabular}{|c|c|c|c|c|c|c|}
\hline $\begin{array}{l}\text { Time exposed to } \\
\text { UV/Ozone (min) }\end{array}$ & $\begin{array}{l}\text { Samples } \\
\text { series }\end{array}$ & $\begin{array}{r}\text { Char } \\
\text { length } \\
(\mathrm{mm}) \\
\end{array}$ & $\begin{array}{c}\text { Burning } \\
\text { time } \\
\text { (sec) }\end{array}$ & $\begin{array}{l}\text { Burning } \\
\text { rate } \\
(\mathrm{mm} / \mathrm{min})\end{array}$ & $\begin{array}{c}\text { Classification } \\
\text { of fabric* }\end{array}$ & Notes \\
\hline \multirow{4}{*}{$\mathbf{0}$} & 1 & 120 & 65 & 111 & \multirow{4}{*}{ Class-3 } & - shrinking \\
\hline & 2 & 120 & 70 & 103 & & - melt dripping \\
\hline & 3 & 120 & 63 & 114 & & $\begin{array}{l}\text { - fast burning } \\
\text { - more smoke }\end{array}$ \\
\hline & Average & 120 & 66 & 109 & & $\begin{array}{l}\text { - not burning } \\
\text { completely }\end{array}$ \\
\hline \multirow{4}{*}{$\begin{array}{l}\text { Coated without } \\
\text { exposed to } \\
\text { UV/Ozone }\end{array}$} & 1 & 120 & 180 & 40 & \multirow{4}{*}{ Class-3 } & - no shrinking \\
\hline & 2 & 120 & 150 & 48 & & - no melt dripping \\
\hline & 3 & 120 & 160 & 45 & & - slow burning \\
\hline & Average & 120 & 163 & 44.3 & & $\begin{array}{l}\text { - more smoke } \\
\text { - burning completel }\end{array}$ \\
\hline \multirow{4}{*}{30} & 1 & 0 & 0 & 0 & \multirow{4}{*}{ Class-1 } & - no burning after 3 \\
\hline & 2 & 0 & 0 & 0 & & sec. \\
\hline & 3 & 0 & 0 & 0 & & $\begin{array}{rr}\text { - shrank } & \text { slightl } \\
\text { during } & \text { ignitio }\end{array}$ \\
\hline & Average & 0 & 0 & 0 & & $\begin{array}{l}\text { only. } \\
\text { • no melt dripping }\end{array}$ \\
\hline \multirow{4}{*}{90} & 1 & 0 & 0 & 0 & \multirow{4}{*}{ Class-1 } & - no burning after 3 \\
\hline & 2 & 0 & 0 & 0 & & sec. \\
\hline & 3 & 0 & 0 & 0 & & $\begin{aligned} \text { - shrank } & \text { slightl } \\
\text { during } & \text { ignitio }\end{aligned}$ \\
\hline & Average & 0 & $\mathbf{0}$ & 0 & & $\begin{array}{l}\text { only. } \\
\text { • no melt dripping }\end{array}$ \\
\hline \multirow{4}{*}{125} & 1 & 0 & 0 & 0 & \multirow{4}{*}{ Class-1 } & - no burning after 3 \\
\hline & 2 & 0 & 0 & 0 & & sec. \\
\hline & 3 & 0 & 0 & 0 & & $\begin{array}{r}\text { - shrank } \\
\text { during }\end{array}$ \\
\hline & Average & $\mathbf{0}$ & $\mathbf{0}$ & $\mathbf{0}$ & & $\begin{array}{l}\text { only. } \\
\text { • no melt dripping }\end{array}$ \\
\hline
\end{tabular}

* The sample can be classified class-1, when the fire not passing first line (after $2.5 \mathrm{~cm}$ from the free end), but when passing this line and stopped (not reached to second line after $7.5 \mathrm{~cm}$ from the first one) it can be classified as class-2, and class-3 refers to complete burning of the sample (fire will be reached to the second line, which found on $10 \mathrm{~cm}$ from the free end).

\subsection{Thermal Degradation Behavior}

The thermal stability of the samples was investigated by means of TGA. The TGA curves are showed in Figures 3 and 4 . Figure 3 illustrates the main pyrolysis stage which occurs in the temperature zone between 315 and $486.4^{\circ} \mathrm{C}$ in the presence of nitrogen gas. At this stage the sample's mass loss is very fast and significant. Major pyrolysis products are produced at this stage. From $486.4{ }^{\circ} \mathrm{C}$ until $750{ }^{\circ} \mathrm{C}$ dehydration and charring reactions tends to be completed. 


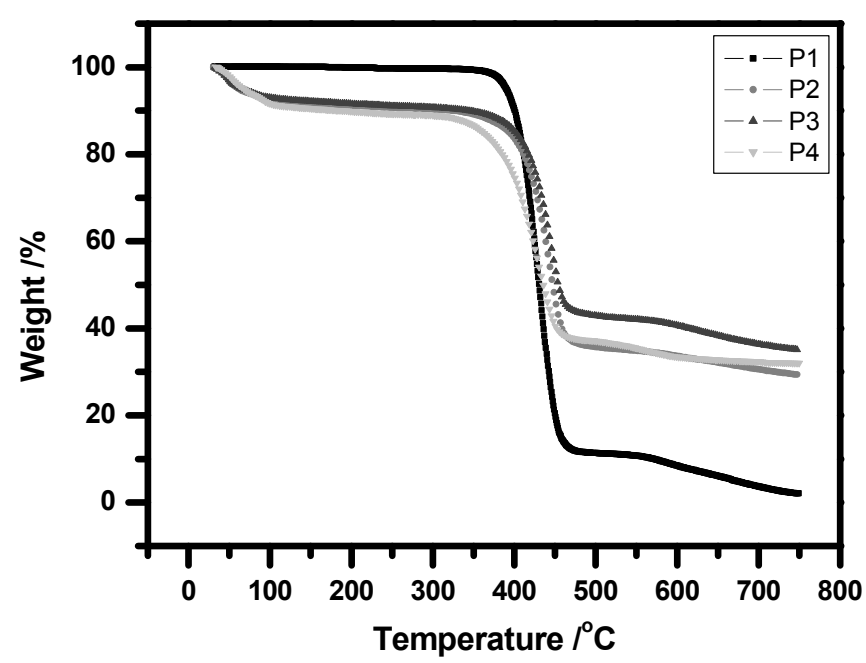

Figure 3. Thermogravimetric studies of untreated and treated samples with phosphorylated sol-gel coating after exposuring to UV/Ozone for different periods (P1 at zero min; P2 at $30 \mathrm{~min}$; P3 at $90 \mathrm{~min} \& \mathrm{P} 4$ for $125 \mathrm{~min}$ ).

The pyrolysis of sample-P1 includes different minor stages explained as follows: the initial stage includes no sample loss. This could be observed up to $355.1{ }^{\circ} \mathrm{C}$. At $355.1^{\circ} \mathrm{C}$, the most significant changes of cellulose begin to occur in some physical properties accompanied by little sample loss. The main pyrolysis stage occurs in the temperature zone between $355.1-486.4{ }^{\circ} \mathrm{C}$ (Figure 3). Major pyrolysis products are produced at this stage. Above $486.4{ }^{\circ} \mathrm{C}$ dehydration \& charring reactions tends to be completed. The best result obtained with treated sample (P3) after irradiating for $90 \mathrm{~min}$ since the weight loss is $66.8 \%$ at $750{ }^{\circ} \mathrm{C}$.

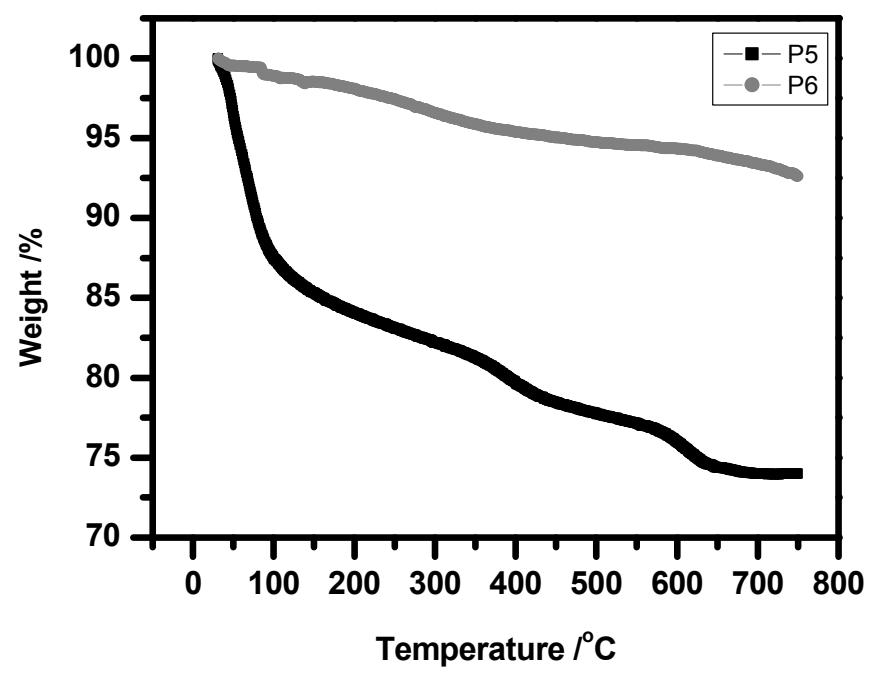

Figure 4. TGA of untreated (P6) \& phosphorylated sol-gel coated polyester (P5) samples

Figure 4 and Table 3 show the effect of adding the phosphoric acid $\mathrm{H}_{3} \mathrm{PO}_{4}$ on thermal behavior of sol-gel coating materials. In Figure 4 untreated sol-gel coating material is represented by $\mathrm{P} 6$ while the one treated with $\mathrm{H}_{3} \mathrm{PO}_{4}$ is represented by P5. It is clear that, there are several distinct thermal degradation behaviors. Treated Sample showed clear improvement in the sample stability up to $700{ }^{\circ} \mathrm{C}$. The $\mathrm{P} 5$ sample includes different major stages explained as follow: the initial stage ends at $155.5^{\circ} \mathrm{C}$ in which the rate of decomposition was very fast. In second $\&$ third stages the rate of decomposition decreased with slow rate until dehydration \& charring reactions were completed at $693.2^{\circ} \mathrm{C}$. This indicates that weight loss of P5 was huge. The P6 sample was decomposed in two stages with very slow rate. The final weight loss at temperature $750{ }^{\circ} \mathrm{C}$ was $27.8 \%$ for $\mathrm{P} 5$, while, $8.7 \%$ for P6. 
Table 3. Thermogravimetric analysis of untreated \& treated PET samples with phosphorylated sol-gel coating after exposuring to UV/Ozone for different periods (P1 at zero min; P2 at $30 \mathrm{~min}$; P3 at $90 \mathrm{~min} \& \mathrm{P} 4$ for 125 min). Sol-gel coating materials were also studied \& represented as P6 for unphosphorylated sample while P5 for phosphorylated sample

\begin{tabular}{|c|c|c|c|c|c|c|c|}
\hline \multirow[b]{2}{*}{$\begin{array}{c}\text { Samples } \\
\text { No. }\end{array}$} & \multicolumn{2}{|c|}{ Stage 1} & \multicolumn{2}{|c|}{ Stage 2} & \multicolumn{2}{|c|}{ Stage 3} & \multirow{2}{*}{$\begin{array}{c}\text { Mass residue } \\
(\%) \\
\text { at } 750{ }^{\circ} \mathrm{C}\end{array}$} \\
\hline & $\begin{array}{c}\text { Temp. } \\
\left({ }^{\circ} \mathrm{C}\right)\end{array}$ & $\begin{array}{l}\text { Mass } \\
\text { residue } \\
(\%)\end{array}$ & $\begin{array}{c}\text { Temp } \\
\left({ }^{\circ} \mathrm{C}\right)\end{array}$ & $\begin{array}{c}\text { Mass } \\
\text { residue } \\
(\%)\end{array}$ & $\begin{array}{c}\text { Temp } \\
\left({ }^{\circ} \mathrm{C}\right)\end{array}$ & $\begin{array}{l}\text { Mass } \\
\text { residue } \\
(\%)\end{array}$ & \\
\hline P1 & 355.1 & 99.7 & 481.4 & 11.6 & 748.0 & 2.1 & 1.9 \\
\hline P2 & 326.0 & 89.7 & 515.5 & 35.1 & 740.0 & 29.3 & 28.1 \\
\hline P3 & 331.0 & 90.3 & 509.8 & 42.7 & 740.1 & 35.5 & 33.2 \\
\hline P4 & 307.0 & 88.3 & 489.0 & 37.4 & 704.4 & 32.2 & 31.5 \\
\hline P5 & 155.5 & 84.7 & 445.4 & 77.9 & 693.2 & 73.1 & 72.8 \\
\hline P6 & -- & -- & 363.3 & 95.5 & 750.0 & 92.2 & 91.3 \\
\hline
\end{tabular}

\section{Conclusions}

Sol-gel processes have been exploited in order to form a silica compact coating on polyester fabrics to enhance their flame retardancy \& thermal stability. The effect of UV/Ozone irradiation on samples has been investigated to get the optimum conditions with respect to mechanical properties and flame retardancy.

\section{Acknowledgements}

The authors thank Prof. Dr. Ferial M. Tera and Prof. Dr. Monira Michael (National Institute for Standards) in addition to Prof. Dr. Mohamed Badr El-Sabbah and Prof. Dr. Abd El-Rahman M. Naser (Al-Azhar University) for their guidance \& help to conduct this work.

\section{References}

Abidi, N., Hequet, E., Tarimala, S., \& Dai, L. (2007). Cotton Fabric Surface Modification for Improved UV-radiation Protection Using Sol-Gel Process. J. Appl. Polym. Sci., 104, 111-117. http://dx.doi.org/10.1002/app.24572

Aegerter, M. A., Mennig, M., Oliveira, P. W., \& Schmidt, H. (2004). Sol-Gel Technologies for Glass Producers and Users (p. 195). Boston: Kluwer Academic Publishers. http://dx.doi.org/10.1007/978-0-387-88953-5

Asrar, J., Berger, P. A., \& Hurlbut, J. (1999). Synthesis and characterization of a fire-retardant polyester: Copolymers of ethylene terephthalate and 2-carboxyethyl(phenylphosphinic) acid. J. Polym Sci. Part A. Polym. Chem., $\quad 37(16), \quad 3119-3128$. http://dx.doi.org/10.1002/(SICI)1099-0518(19990815)37:16\%3C3119::AID-POLA9\%3E3.0.CO;2-7

ASTM. (2009). Standard Test Method for Breaking Strength \& Elongation Length.

Bamoniri, A., Mirjalili, B. B. F., \& Nazemian, S. (2012). Nano-Silica phosphoric acid: an efficient catalyst for one-pot synthesis of 3,4-dihydropyrimidin-2(1H)-ones (thiones) under solvent-free or sonication conditions. J. Iran Cat., 2(1), 17-21.

Boekhoff, K. (2012, September 16). USES. Retrieved from http://schwartz.eng.auburn.edu/polyester/uses.html

Bozzi, A., Yuranova, T., Guasaquillo, I., Laub, D., \& Kiwi, J. (2005). Self-cleaning of modified cotton textiles by $\mathrm{TiO}_{2}$ at low temperatures under daylight irradiation. J. Photochem Photobiol. A-Chem., 174, 156-164. http://dx.doi.org/10.1016/j.jphotochem.2005.03.019

Brinker, C. J., \& Scherer, G. W. (1990). Sol-Gel Science: The Physics and Chemistry of Sol-Gel Processing. USA: Academic Press.

Brinker, C. J., \& Mukherjee, S. P. (1981). Conversion of monolithic gels to glasses in a multi-component silicate glass system. J. Mat. Sci., 16, 1980-1988. http://dx.doi.org/10.1007/BF00540646 
Chapple, S. A., \& Ferg, E. (2006). The Influence of Precursor Ratios on the Properties of Cotton Coated with a Sol-gel Flame Retardant. AATCC Review, 6(11), 36-40.

Daoud, W. A., \& Xin, J. H. (2004). Nucleation and Growth of Anatase Crystallites on Cotton Fabrics at Low Temperatures. J. Am. Ceram. Soc., 87(5), 953-955. http://dx.doi.org/10.1111/j.1551-2916.2004.00953.x

Dislich, H. (1971). New Routes to Multicomponent Oxide Glass. Angewandte Chemie International Edition in English, 10(6), 363-370. http://dx.doi.org/10.1002/anie.197103631

Erdem, N., Cireli, A., \& Erdogan, U. (2009). Flame retardancy behaviors and structural properties of polypropylene/nano- $\mathrm{SiO}_{2}$ composite textile filaments. J. Appl. Polym. Sci., 111, 2085-2091. http://dx.doi.org/10.1002/app.29052

Ge, X. G., Wang, C., Hu, Z., Xiang, X., Wang, J. S., Wang, D.Y., ... Wang, Y. Z. (2008). Phosphorus-containing telechelic polyester-based ionomer: Facile synthesis and antidripping effects. J. Polym. Sci., 46(9), 2994-3006.

Geffcken, W., Berger, E., \& Schott, G. (1943). Anti-Reflective Coating. German Patent 736411.

Goodman, I., \& Sheanan, R. J. (1990). Copolyesteramides-VI. Hexamethylene adipamide/hexamethylene adipate random and ordered copolymers: molecular aspects. J. Eur. Polym., 26(10), 1089-95. http://dx.doi.org/10.1016/0014-3057(90)90008-R

Hribernik, S., Smole, M. S., Kleinschek, K. S., Bele, M., Jamnik, J., \& Gaberscek, M. (2007). Flame retardant activity of $\mathrm{SiO}_{2}$-coated regenerated cellulose fibres. Polym Degrad Stab., 92(11), 1957-1965. http://dx.doi.org/10.1016/j.polymdegradstab.2007.08.010

Ibrahim, S. F., El-Nagar, Kh., \& Tera, F. M. (2012). Improving Wool Printability at Reduced Energy Using UV/Ozone Treatment, RJTA. Accepted for publication.

Ikesue, A. (2002). Polycrystalline Nd: YAG Ceramics Lasers. Optical Materials. 19, 183-185. http://dx.doi.org/10.1016/S0925-3467(01)00217-8

Ikesue, A., Kinoshita, T., Kamata, K., \& Yoshida, K. (1995). Fabrication and optical properties of high-performance polycrystalline Nd:YAG ceramics for solid-state lasers. J. Am. Ceram. Soc., 78(4), 1033-1040. http://dx.doi.org/10.1111/j.1151-2916.1995.tb08433.x

ISO-1210. (1992). Determination of burning behavior of horizontal and vertical samples in contact with a small-flame ignition source.

Klein, L. C. (1994). Sol-Gel Optics: Processing and Applications (p. 345). Boston: Kluwer Academic. http://dx.doi.org/10.1007/978-1-4615-2750-3

Kuenpong, P., \& Charuchinda, S. (2009). Effects bentonite, sericin powder and phosphorus compounds on the thermal and fire properties of polyester nonwoven fabric. Proceeding of the 10th Asian Textile Conference (ATC-10). September 7-9, Ueda, Japan: 150.

Lerdkajornsuk, P., \& Charuchinda, S. (2010). Study on Flame Retardancy and Anti-Dripping of polyester fabric treated with bentonite, diammonium hydrogen phosphate and aluminium hydroxide. J. Met. Mat. Miner., 20(2), 63-70.

Marazzato, C., Peneva, Y., Lefterova, E., Filippi, S., \& Minkova, L. (2007). Kinetics of non-isothermal degradation of nanocomposites based on functionalized polyethylenes. Polym. Test., 26(4), 526-536. http://dx.doi.org/10.1016/j.polymertesting.2007.01.006

Matijevic, E. (1986). Monodispersed colloids: art and science. Langmuir, 2(1), 12-20. http://dx.doi.org/10.1021/la00067a002

Meilert, K. T., Laub, D., \& Kiwi, J. (2005). Photocatalytic self-cleaning of modified cotton textiles by $\mathrm{TiO}_{2}$ clusters attached by chemical spacers. J. Mol. Catal. A-Chem., 237, 101-108. http://dx.doi.org/10.1016/j.molcata.2005.03.040

Mostashari, S. M., Kamali, Y. N., \& Fayyaz, F. (2008). Combustion pathway of cotton fabrics treated by ammonium sulfate as a flame-retardant studied by TG. J. Therm. Anal. Cal., 91, 237-241. http://dx.doi.org/10.1007/s10973-006-8276-9

Müller, P. (1994). Glossary of terms used in physical organic chemistry (IUPAC Recommendations 1994). Pure Appl. Chem., 66, 1077-1184. http://dx.doi.org/10.1351/pac199466051077

Nour, M., Eid, A., El-Nagar, Kh., \& Abdelaziz, F. (2010). Preparation and characterization of polyethylene/clay 
nanocomposites as a flame retardant materials using ultrasonic technique. Polym. Comp., 18(3), 159-166.

Philippou, J. (2000). Sol-Gel: A Low temperature Process for the Materials of the New Millennium.

Prochazka, S., \& Klug, F. J. (1983). Infrared-transparent mullite ceramics. J. Am. Ceram Soc., 66, 874-880. http://dx.doi.org/10.1111/j.1151-2916.1983.tb11004.x

Rohringer, P., Stensby, T., \& Adler, A. (1975). Mechanistic Study of Flame Inhibition by Phosphonate- and Phosphonium-Based Flame Retardants on Cotton and Polyester Fabrics. Text. Res. J., 45, 591-595. http://dx.doi.org/10.1177/004051757504500803

Sakka, S., \& Kamiya, K. (1980). Glasses from metal alcoholates. J. Non-Cryst. Solids., 42, 403-422. http://dx.doi.org/10.1016/0022-3093(80)90040-X

Sequeira, S., Evtuguin, D. V., Portugal, I., \& Esculcas, A. P. (2007). Synthesis and characterisation of cellulose/silica hybrids obtained by heteropoly acid catalysed sol-gel process. Mater. Sci. Eng., 27, 172-179. http://dx.doi.org/10.1016/j.msec.2006.04.007

Shao, J., Carr, C. M., Rowlands, C. P., \& Walton, J. (1999). XPS, SIMS, and ESR Studies of UV/Ozone-Irradiated Silk and Wool. J. Tex. Inst., 90(4), 459-468.

Song, S. L., Hu, Y., Tang, Y., Zhang, R., Chen, Z. Y., \& Fan, W. C. (2005). Study on the properties of flame retardant polyurethane/organoclay nanocomposite. Polym. Degrad. Stab., 87(1), 111-116. $\mathrm{http}: / / \mathrm{dx}$. doi.org/10.1016/j.polymdegradstab.2004.07.012

Uddin, M. J., Cesano, F., Bonino, F., Bordiga, S., Spoto, G., Scarano, D., \& Zecchina, A. (2007). Photoactive $\mathrm{TiO}_{2}$ films on cellulose fibres: synthesis and characterization. J. Photochem Photobiol A-Chem., 189, 286-294. http://dx.doi.org/10.1016/j.jphotochem.2007.02.015

Wang, R. H., Xin, J. H., Tao, X. M., \& Daoud, W. A. (2004). ZnO nanorods grown on cotton fabrics at low temperature. J. Chem. Phys. Lett., 398, 250-255.

Wilson, W. E., O’Donovan, J. T., \& Fristrom, R. M. (1969). Flame inhibition by halogen compounds. $\begin{array}{lllll}\text { Symposium } \quad \text { (International) } & \text { 9 }\end{array}$ http://dx.doi.org/10.1016/S0082-0784(69)80472-8

Wright, J. D., \& Sommerdijk, N. A. (2001). Sol-Gel Materials: Chemistry and Applications (p. 43). Amsterdam: Gordon \& Breach.

Wu, W., Qu, H., Li, Z., \& Yu, H. (2008). Thermal behavior and flame retardancy of flexible poly(vinyl chloride) treated with zinc hydroxystannate and zinc stannate. J. Vinyl. Addit. Technol., 4, 10-15. http://dx.doi.org/10.1002/vnl.20123

Yoldas, B. E. (1979). Monolithic glass formation by chemical polymerization. J. Mat. Sci., 14, 1843-1849. http://dx.doi.org/10.1007/BF00551023

Younis A. A., El-Sabbah, M. M. B., \& Holze, R. (2012). The effect of chloride concentration and pH on pitting corrosion of AA7075 aluminum alloy coated with phenyltrimethoxysilane. J. Solid State Electrochem., 16, 1033-1040. http://dx.doi.org/10.1007/s10008-011-1476-7

Younis, A. A. (2011). Protection of Aluminum Alloy (AA7075) from Corrosion by Sol-Gel Technique (PhD thesis, Chemnitz University of Technology). Retrieved from http://nbn-resolving.de/urn:nbn:de:bsz:ch1-qucosa-83230

Younis, A. A., Ensinger, W., El-Sabbah, M. M. B., \& Holze, R. (2012). Corrosion protection of pure aluminium and aluminium alloy (AA7075) in salt solution with silane-based sol-gel coatings. Materials and Corrosion, 2012. http://dx.doi.org/10.1002/maco.201206691

Zhu, P., Sui, S., Wang, B., Sun, K., \& Sun, G. (2004). A study of pyrolysis and pyrolysis products of flame-retardant cotton fabrics by DSC, TGA, and PY-GC-MS. J. Anal. Appl. Pyrolysis, 71, 645-655. http://dx.doi.org/10.1016/j.jaap.2003.09.005 